\title{
Corruption, Emotional Intelligence, and Leadership: Leadership Analysis From The Seventh President of the Republic of Indonesia
}

\author{
Pustaka Bangun \\ Universitas Pertahanan \\ E-mail: pbangun85@yahoo.co.id
}

Aries Djaenuri

Institut Pemerintahan Dalam Negeri

Lalu Wildan

Institut Pemerintahan Dalam Negeri

Received: Nov. 11, 2019 Accepted: Jan. 10, 2020 Online published: Feb. 4, 2020

doi:10.5296/jpag.v10i1.15795 URL: https://doi.org/10.5296/jpag.v10i1.15795

\begin{abstract}
After the proclamation of Indonesian independence on August 17, 1945, the founding fathers of the nation formulated the objectives of the Indonesian state as stated in the preamble of the 1945 Constitution. In an effort to achieve the intended national goals, the President of the Republic of Indonesia, since the era of President Sukarno until now namely President Joko Widodo has implemented various policies. One of the national policies in the reform era, namely the 1990s, was a change in the principle of government from centralization to decentralization. Since the implementation of the decentralization principle there have been two prominent issues relating to the Regional Head First, the number of Regional Heads sentenced to prison for committing corruption and accepting bribes. Secondly, the emergence of Joko Widodo, who in his second term as Mayor of Solo, was elected as the Governor of DKI Jakarta Province in 2012 to 2017, and later in the 2014 Presidential election, was elected as the seventh President of the Republic of Indonesia. The success of Joko Widodo to gain the above achievements mostly because Joko Widodo implemented the dimensions of transformational leadership and dimensions of emotional intelligence in his leadership so that
\end{abstract}


the community and staff were satisfied and then provided support to him. The author believes that Joko Widodo 'i childhood experience, religious practices, Javanese culture practices, and furniture business experience formed the dimensions of emotional intelligence and transformational leadership dimensions in Joko Widodo's leadership.

Keywords: emotional intelligence, transformational leadership, corruption eradication

\section{Introduction}

Decentralization has not all been successful. According to Bertucci and Senese (2007: 49), endemic problems in the strata of local government such as corruption, poverty and lack of adequate infrastructure, complicated access to the availability of resources, significantly impedes the process of decentralization, and corruption is a dangerous barrier to decentralization. Regarding corruption in the era of decentralization in Indonesia, Hadiz (2010: 176) quoting the Jakarta Post daily on December 5, 2005 revealed, in Kalimantan, for example, no less than 10 Bupatis were convicted of illegal logging and embezzlement of government reforestation funds. In addition, successful local politicians such as Medan Mayor, Abdillah and Kutai Kartanegara Regent, Syaukani were also involved in serious corruption cases.

Corruption by regional heads in Indonesia never stops. In the Kompas daily ("Benahi Pengawas", October 09, 2017) it was reported, since the Corruption Eradication Commission (KPK) was established in 2003, as many as 77 regional heads were affected by arresting operations, 335 regional heads were involved in the problem of corruption, and more than five the head of the area was arrested in the past six months for allegedly taking bribes. The same media returned the news about the arrests of the Regent of Jombang, the Regent of Ngada and the Regent of Subang by the Corruption Eradication Commission due to alleged corruption (Kompas, "Corruption Emergency", February 15, 2018).

Regarding corruption in Indonesia, Hadiz (2010: 36) states that Indonesia is one of the most corrupt countries. Hadiz expressed Wee's opinion (2002: 5) which states that in the 1998 survey (when the Soeharto government fell), Indonesia was ranked 80th out of 85 countries surveyed in terms of corruption. Hadiz continued, based on data from Transparency International in 2001, Indonesia was ranked as the 3rd most corrupt country, and in 2002 was ranked 4. In 2003, Indonesia ranked 122 out of 133 countries surveyed, and in 2006 ranked 130th from 163 countries surveyed.

Related to corruption in the bureaucratic environment, Riggs (2009: 89) states, bureaucracy as rulers often exploit their offices for personal interests such as corruption and bribery which are deviant and immoral acts. Meanwhile, according to Nahavandi (2009: 140), the characteristics of bad leaders include corruption, incompetence and lack of care for others. From the various opinions above, it is very clear that the bureaucracy or regional head who is corrupt, manipulating the regional income and expenditure budget and accepting bribes for personal, family or group interests because the regional head's leadership is weak, does not care about the community, immoral and unable to control themselves. Self-control according to Goleman (1998: 32), is one of the dimensions of emotional intelligence. Someone who is 
able to control himself means that someone has good emotional intelligence, and vice versa if someone is not able to control themselves, it means that one's emotional intelligence is not good.

Actually, emotional intelligence, the tendency of corrupt behavior and the competency of regional head candidates can be known through a series of competency tests including psychological tests conducted by the Regional Election Commission (KPUD) during the registration of prospective regional heads. But the KPU has never announced the results to the public so that the public as a voter does not know the competence, emotional intelligence and behavioral tendencies of the candidates for the regional head. The impact is that people only choose regional head candidates who share their money during the campaign period. Another phenomenon is marked by the emergence of several regional heads who have great concern for development in their area, including Joko Widodo. According to Nurulloh (2013: iii), a number of international media such as CNN, The Economist, Time and The New York Time see Joko Widodo as "phenomenal", and also as an oasis in the midst of the drying up of populist Indonesian officials, far from the reach of the people. Jokowi is known for the "blusukan" jargon which turned out to be not just jargon, but Jokowi has proven it in the field. Kompas (Amazingly the leader of the region, March, 3.2016) mentioned the names of a number of regional leaders who were categorized as givers of hope, one of whom was Joko Widodo, who had served as the Mayor of Solo and the Governor of DKI Jakarta Province.

According to Zulkarnain and Harris (2017: 1) Joko Widodo's presence in Indonesian national politics is considered by some parties to be phenomenal because in the political age of 9 years he was elected President of the Republic of Indonesia in the 2014 Presidential election after serving as Mayor of Solo (2005-2010) and the Governor of DKI Jakarta (2012-2014). Furthermore, Zulkarnain and Harris mentioned several nicknames given by a number of mass media and individuals to Joko Widodo, among others: the street democracy (Joko Widodo because Joko Widodo used his time more to meet and listen to various kinds of hopes and demands of the people), Obama from Jakarta, Mr. Fix, The man in the Madras Shirt (because Jokowi is considered successful in wearing plaid clothes during the campaign in the Jakarta Governor Election), man of the people (because he is considered a clean politician and is considered successful in clearing Tanah Abang street vendors and normalizing Pluit Reservoir).

After the implementation of the principles of decentralization and regional autonomy, many emerging regional heads were considered good. Kompas (Amazingly the leader of the region, March, 3.2016) mentioned Joko Widodo as one of the regional heads who was categorized as a giver of hope. Nurulloh (2013: iii) states a number of international media view Joko Widodo as "phenomenal". According to Zulkarnain and Harris (2017: 1), Joko Widodo's presence in Indonesian national politics is considered by some to be phenomenal. Regarding Joko Widodo's leadership, Amirsyah (2014: 14) states that Joko Widodo applies transformational leadership and serving leadership. Zulkarnain and Harris (2017: 1930) state, Joko Widodo's leadership model varies namely servant, populist, and democratic. This is in line with the expression of Zubaidi (2014) which says that "Joko Widodo's leadership in the dimension of listening, the dimension of empathy, the healing dimension, the dimension of 
self-awareness, the dimension of persuasion, the dimension of conceptualization, and the forecasting dimension, are in the good category". Joko Widodo according to Yuwono's research (2016) getting success when he was the Mayor of Solo was the ideology of the leader, the innovation of the leader, the motivation of the leader and the firmness of the leader.

\section{Methods}

This research is qualitative research. Background on the selection of qualitative design because the phenomenon under study is specific, namely aspects of emotional intelligence and transformational leadership in Joko Widodo's leadership that requires detailed and in-depth answers from informants. This is in accordance with Sugiyono's opinion (2015: 13) which states, qualitative research is used to obtain deep data (data that contains meaning). Determination of the informant in accordance with the opinion of Sugiyono (2016: 56) which states, the criteria of the informant include: being involved or being part of the activities and phenomena that are being the object of study, and can be used as a teacher or resource person. In connection with data collection, the writer uses interviewing, documentation and triangulation techniques based on Sugiyono's opinion (2015: 308, 2016: 62). While the technique of analyzing data, using the stages formulated by Yin (2011: 176), namely: compiling, disassembling reassembling, interpreting and concluding. The study was conducted in Solo and Jakarta.

\section{Research Result and Discussion}

\section{The Application of the Dimension of Emotional Intelligence in Joko Widodo's Leadership}

With the ability to realize self-emotion, Joko Widodo has created a comfortable work environment for staff so that staff is motivated to work harder. In terms of confidence, Joko Widodo's confidence is relatively high. Confidence as above is very likely formed by experience, family, community, think tank, and intellectual intelligence. Staff who have a confident leader will be more confident in carrying out the task so that a positive impact on organizational performance. Regarding self-assessment, Joko Widodo realized that he did not fully master governance. Nevertheless, Joko Widodo is an intelligent leader, and this can be seen from his willingness to use experts or think tanks to help him formulate the concept of development, and carry out supervision so that the achievement of the vision and mission of his government is more secure.

Joko Widodo's attitude that does not express his abilities is a humble attitude. Such an attitude will strengthen Joko Widodo's relationship with staff so as to create teamwork towards efforts to improve organizational performance. In terms of controlling and diverting negative emotions, Joko Widodo is able to control and divert negative emotions. such abilities make the work atmosphere comfortable so that staff motivation increases. However, if Joko Widodo finds staff not optimally serving the community, Joko Widodo tends to be less able to control his emotions. The events of the data bundle throwing at the East Jakarta Mayor's office can be used as evidence. 
Regarding adaptation, Joko Widodo is an adaptive person, willing to accept and respect the opinions of others so that people feel proud and satisfied even if their opinions will not be implemented. This adaptability is in line with the results of Zubaidi's research (2014), namely Joko Widodo's leadership in the listening dimension is in a good category. The listening indicators include, actively listening to the suggestions, opinions, and complaints of citizens. By referring to Kaswan's opinion (2017: 175), by listening to other people, Joko Widodo has shown respect for that person, Joko Widodo earns the trust of the community or staff, Joko Widodo's relationship with the community and staff is built, Joko Widodo's knowledge and insight and ideas increasing, and the community or staff more loyal to Joko Widodo. From the explanation above, with this adaptive ability, Joko Widodo has a psychological advantage, namely that more people and staff are sympathetic and supportive of the government programs they lead. In terms of prudence, Joko Widodo considers aspects of community interests, rules, city beauty, and budget availability before formulating a decision. By placing the interests of the community as the main consideration, it shows Joko Widodo's concern for the community is very high. Concern is very likely formed by his childhood experience. Likewise, considering the rules and availability of the budget, it appears that Joko Widodo is a law-abiding leader.

Joko Widodo's ability to maintain his integrity is an indicator that Joko Widodo qualifies as a qualified leader as McMaster's opinion (1999: 280) states that the basic quality possessed by a successful leader is integrity. This, also in accordance with the opinion of Yukl (2010: 28) which states the measure of the effectiveness of the leader in carrying out his leadership, among others, is whether followers perceive the leader with integrity. Furthermore, the various awards received by Joko Widodo, the implementation of various infrastructure developments, and the absence of legal problems affecting Joko Widodo are indicators that Joko Widodo consistently maintains his integrity. This consistency is shaped by family education, the practice of Javanese religious and cultural values, and life experiences. With the maintenance of self-integrity, Joko Widodo is increasingly trusted, respected, respected and respected by the community and staff. On the point of commitment, Joko Widodo is a leader who keeps promises. Joko Widodo was elected Mayor of Solo for a second term, became Governor of DKI Jakarta in 2012, and was elected President of Indonesia in 2014 and 2019 because the public saw Joko Widodo always keep his promises.

On the point of initiative, Joko Widodo's leadership quality is in accordance with McMaster's opinion (1999: 280) which states that one of the basic qualities possessed by a successful leader is having an initiative that means having a lot of sense, acting quickly in an emergency, and having extraordinary skills to work together with other people. The initiative contained in Joko Widodo's leadership is also in accordance with Pamudji's opinion (1995: 90) which states that one of the qualities that need to be developed by government leaders in Indonesia is "full of the initiative" as a source of inspiration. According to the author, many of Joko Widodo's initiatives were formed by his intellectual intelligence and experience as a businessman and leading a furniture organization, and subsequently became a motivator for staff to grow initiatives which then had a positive impact on the performance of the government led by Joko Widodo. 
In the "optimistic" item, Joko Widodo is an optimistic leader who then encourages the growth of the staff's optimistic attitude to work harder. The optimistic attitude found in Joko Widodo is very likely to be shaped by experience as a furniture businessman, community support, confidence, not involved in KKN, and think tank support. In the "drive for achievement" item, Joko Widodo's character is seen as a businessman who prioritizes speed and quality to satisfy customers. Such character is applied by Joko Widodo to the government with the aim that the community gets the best service. With the realization of the maximum service, it is reasonable if the community then supports Joko Widodo in the elections of Solo, Jakarta and the 2014 and 2019 presidential elections.

On the point of "understanding other people", Joko Widodo understands what the staff is feeling. By understanding this, Joko Widodo is easier to determine how to treat staff so that staff feels close, respectful and increasingly motivated to work. The realization of a close relationship between Joko Widodo and staff because Joko Widodo knows the staff's thoughts and emotions. Joko Widodo's ability to understand the thoughts and emotions of staff is in accordance with the results of Zubaidi's research (2014), one of the conclusions being: Joko Widodo's leadership in the empathy dimension is in a good category. On the point of "arousing enthusiasm or raising staff self-esteem", Joko Widodo always evokes enthusiasm and self-esteem of staff so that staff is motivated to improve performance. Joko Widodo's behavior that elevates staff self-esteem shows the quality of Joko Widodo's leadership as Collons (1999: 38) argues that states the leader has certain characteristics which among other things, have social skills that are not degrading group members in front of other members.

In the item "realizing staff welfare", the author believes that Joko Widodo's attention to staff welfare is very high. Such attention is a factor that causes staff to be more sympathetic, respectful, and loyal to Joko Widodo, and this makes it easy for Joko Widodo to move his staff to achieve organizational goals. On the point of "giving equal space, time and opportunity to various community groups", it is seen that Joko Widodo respects pluralism which is one of the characteristics of the Indonesian nation. Regarding Joko Widodo's attitude towards pluralism, Ambarita et al (2012: 25) revealed Joko Widodo's Muslim friendship with Catholic Toto. As friends and neighbors, they often went together to school a distance of approximately $1 \mathrm{~km}$ from Tirtoyoso village. Joko Widodo, who has a bicycle, spiked with Toto who does not have a bicycle.

With respect to pluralism, Joko Widodo not only creates a peaceful and comfortable atmosphere for the community but also for staff who are ethnically and religiously different from Joko Widodo. Such conditions will encourage staff to work wholeheartedly to support Joko Widodo's leadership so that government performance is getting better, and this is in accordance with the opinions of Naylin (1999: 133) and Collins (1999: 25) which states, employee productivity is influenced, among others, by fair treatment from superiors. According to the author, Joko Widodo's attitude towards pluralism is shaped by the family environment, his understanding of the history of the struggle of the Indonesian people and Pancasila. On the point "the ability to understand the atmosphere of various political groups and the ability to put themselves in that atmosphere", it was seen that Joko Widodo was able to establish harmonious relations with political groups. Such a relationship is a capital for 
Joko Widodo in planning and implementing various development programs without worrying about facing opposition from the legislature so that people can get services more quickly which then has an impact on increasing people's satisfaction and trust in Joko Widodo.

In emotional "influence" skills, there are two aspects that cause staff to carry out Joko Widodo's direction. First, there is a people's mandate to Joko Widodo. Second, Joko Widodo's personality or behavior is relatively clean from negative deeds. Such leaders must be respected, respected and valued by staff, and staff certainly carry out Joko Widodo's direction. In emotional communication skills, Joko Widodo has the ability to establish good communication with staff. This ability is consistent with the opinion of Pamudji (1995: 90) which states, one of the characteristics that need to be developed by government leaders in Indonesia is communicative. Joko Widodo's ability to communicate is very likely influenced by Joko Widodo's personality who always wants to be friends, experience as a furniture businessman, social and family environment, practice of Javanese culture, and religious education. In the context of the interests of governance, good communication between Joko Widodo and staff has the potential to improve the performance of the government led by Joko Widodo.

Regarding emotional skills "the ability to resolve conflicts", Joko Widodo was able to resolve conflicts between himself and other parties. This ability is very likely influenced by Joko Widodo's personality who is humble, willing to budge, and prefers to be friends so that he is willing to come to or invite those who are in conflict with him. With his ability to resolve conflicts, Joko Widodo is easier to run the government to serve the community. In the emotional prowess of "pioneering in renewal", Joko Widodo is a pioneer figure in reform. Pioneering work of Joko Widodo is very likely influenced by several factors including his experience as a businessman, family support and think tanks, and religious practice. His pioneering work, especially his attitude of not willing to accept deposits, has a positive impact on changes in the behavior of his staff so that the principle of "good governance" is more easily achieved.

On the emotional prowess of "building close relationships with staff", Joko Widodo is easy to establish close relationships with staff. Such abilities are very likely to be shaped by the family environment, his experience as a businessman, and the practice of Javanese religion and culture. The realization of close relations with the staff has the potential to improve government performance. Regarding collaboration, conducted by Joko Widodo, this is in accordance with the opinion of Wanna (2008: 3), Carmody (2008: 61) and Denhardt and Denhardt (2011: 420) which states, developing collaboration is one of the imperatives of leadership in government. According to the author, Joko Widodo's willingness to collaborate might be influenced by workload, service speed, and community participation needs.

In emotional ability "to accommodate the opinions of others, Joko Widodo is open to various inputs for the benefit of the community. Joko Widodo's openness may be influenced by various factors such as his experience as an entrepreneur, the development of information technology and his social environment. This openness, in addition to satisfying those who give advice, also benefits Joko Widodo, which is that more staff and the public are 
sympathetic to him. This condition is capital for Joko Widodo to get greater support for the interests of his political career.

\section{Application of Transformational Leadership Dimensions in Joko Widodo's Leadership}

Joko Widodo's exemplary and the respect, trust, and respect of staff made it easier for Joko Widodo to realize good governance. This example can also be a factor that influences community support for Joko Widodo's leadership to continue development for the improvement of the nation's social economy. Regarding motivating and inspiring, Staff is motivated and inspired by Joko Widodo's leadership. Joko Widodo's leadership that inspires staff in accordance with the opinion of Pamudji (1995: 90) which states, one of the traits that need to be developed by government leaders in Indonesia is full of initiatives that mean sources of inspiration.

Staff who are motivated and inspired by Joko Widodo's leadership will be moved to do the best for the organization, including providing better service to the community. In terms of being innovative and creative, Joko Widodo is an innovative and creative figure. Furthermore, staff who have innovative and creative leaders naturally strive to be innovative and creative staff. The growth of this desire will improve the performance of the government, especially in providing services to the community. Some factors which according to the author influence the formation of innovative and creative behavior in Joko Widodo include: experience in the furniture business, think tank support, information technology development, organizational experience, and experience while in government.

In terms of resource persons, Joko Widodo's ability to be a speaker was motivated by his willingness to listen to the opinions of others, especially from intellectual circles, and his mastery of governance and other fields such as economics, and politics. Whereas regarding the direction of technical work, Joko Widodo is not possible to provide technical direction to the staff given the limited mastery of Joko Widodo in each work unit, and the relatively large workload. Regarding the field supervision conducted by Joko Widodo, the supervision was only effective during the term of office of the Mayor of Solo because the area of the city of Solo was only $4 \mathrm{~km}$ square. In the case of preparing candidates for leadership, the official auction conducted by Joko Widodo aims to obtain candidates for leadership candidates with integrity and competence so that when they take office later, the candidate is able to provide maximum public service, and not to misuse.

\section{Closing}

During his time as Mayor of Solo, Governor of DKI Jakarta Province and President of Indonesia, Joko Widodo implemented the dimension of emotional intelligence and the dimension of transformational leadership. Of the five dimensions of emotional intelligence, the dimension of self-control, the dimension of empathy and the dimension of social skills are more dominant than the other dimensions. Whereas the more dominant dimension in transformational leadership is the ideal influence dimension, inspirational motivation, and intellectual stimulation dimension. The central government $c q$ the Ministry of Home Affairs strengthened cooperation with the KPU to formulate psychological testing materials and 
graduation standards for prospective regional heads before being declared entitled to participate in the election campaign. The test material must be able to provide an overview of the quality dimensions of emotional intelligence and the dimensions of transformational leadership found in the leadership of prospective candidates. The test results were announced to the public for consideration before the vote.

\section{Reference}

Ambarita, et al. (2012). Jokowi: Spirit Bantaran Kali Anyar.Jakarta: Elek Media Komputindo.

Carmody, S. (2008). What Works and Why: Collaborating in A Crisis. Dalam Collaborative Governance A New Era of Public Policy in Australia? O'Flynn, Janine dan Wanna, John (Ed). Canberra: ANU E Press. https://doi.org/10.22459/CG.12.2008.07

Collins, F. J. (1999). Cara Memotivasi Pegawai Anda. Dalam Seri Manajemen Sumberdaya Manusia: Memotivasi Pegawai.Timpe, Dale, A. Alih Bahasa: Bididharmo,Susanto. Jakarta: Gramedia.

Collons, D. R. (1999). Menyoroti Sifat Sifat Kepemimpinan. Dalam Seri Manajemen Sumber Daya Manusia: Kepemimpinan.Editor: Timpe, Dale, A.AlihBahasa: Boedidharmo, Susanto. Jakarta: Gramedia

Goleman, D. (1998). Working with Emotional Intelligence. New York: Bantam. https://doi.org/10.1002/lt1.40619981008

Hadiz, R. V. (2010). Localising Power in Post-Authoritarian Indonesia: A Southeast Asia Perspective. Stanford, California: Stanford University Press.

Kaswan. (2017). Psikologi Industri dan Organisasi. Bandung: Alfabeta.

McMaster, I. (1999). Kepemimpinan Dilihat Dari Sudut Pandang Baru.Seri Manajemen Sumber Daya Manusia: Kepemimpinan. Editor: Timpe, Dale, A.Alih Bahasa: Boedidharmo, Susanto. Jakarta: Gramedia

Nurulloh. (2013). Jokowi (Bukan) untuk Presiden kata warga tentang DKI. Jakarta: Elex Media Komputindo.

Pamudji, S. (1995). Kepemimpinan Pemerintahan di Indonesia.Bumi Aksara: Jakarta.

Sugiyono. (2016). Memahami Penelitian Kualitatif. Bandung: Alfabeta.

Wanna, J. (2008). Collaborative Government: Meanings, Dimensions, Drivers and Outcomes. Dalam Collaborative Governance A New Era of Public Policy in Australia? O'Flynn, Janine dan Wanna, John (Ed). Canberra: ANU E Press. https://doi.org/10.22459/CG.12.2008.01

Yin, K. R. (2011). Qualitative Research from Start to Finish. New York: The Guilford Press.

Yukl, G. (2010). Leadership in organizations (7th ed.). Upper Saddle River: PrenticeHall.

Zulkarnain, A., dan Harris, S. (2017). Fenomena Blusukan Dalam Model Kepemimpinan Politik Joko Widodo. Jurnal Kajian Politik Dan Masalah Pembangunan, 13(1). 


\section{Copyright Disclaimer}

Copyright for this article is retained by the author(s), with first publication rights granted to the journal.

This is an open-access article distributed under the terms and conditions of the Creative Commons Attribution license (http://creativecommons.org/licenses/by/4.0/). 